\title{
Caregivers Experience in Performing Interpersonal Communication and Directive Speech Acts With Elderly in Japan and Bali Nursing Home
}

\author{
Ni Komang Purwaningsih and Agus Darma Yoga Pratama \\ ${ }^{I}$ STIKES BINA USADHA Bali-Indonesia \\ ${ }^{2}$ Universitas Warmadewa, Denpasar, Bali-Indonesia \\ agusdarmayoga85@yahoo.com

\begin{tabular}{|l|l|}
\hline Received: $17 / 04 / 2020$ & Revised: 23/04/2020 \\
\hline How to cite (in APA style): & Published: 27/04/2020 \\
Susini, M. (2020). Overcoming Implicit Meaning in Indonesian-English Translation. RETORIKA: Jurnal Ilmu Bahasa, 6 \\
(1), 78-84. doi: https://doi.org/10.22225/jr.6.1.1659.78-84 \\
\hline
\end{tabular}

\begin{abstract}
An increasing number of elderly in Japan and Indonesia, especially Bali, has led to increased health needs to care for them in nursing homes. Health workers, such as caregivers, are the closest people to communicate directly with the elderly. Communication can be called interpersonal communication which is a process of direct information or transfer of understanding of two or more people. Good interpersonal communication will build closeness and intimacy in the process of delivering messages. Therefore this study tried to analyze the experience of caregivers in implementing interpersonal communication and also determine the form of directive speech acts used by caregivers in caring for the elderly in nursing homes. The method used in this research was a qualitative descriptive method by phenomenological approach. The results showed that interpersonal communication applied by caregivers in caring for the elderly provided verbal and non verbal interpersonal communication. In addition, in the communication process of caregive-elderly is also formed directive speech act including prohibitions, requests and questions. In conclusion, caregivers need to have the ability to communicate effectively with elderly.
\end{abstract}

Keywords: Caregivers, elderly, interpersonal communication, directive speech acts

\section{INTRODUCTION}

Nowadays many countries experience progressive increases in the elderly population, and greater service needs for elderly (Saadati, Shoaee, Pouryan, Alkasir, \& Lashani, 2014) like occurs in Japan which has a fairly large elderly population, more than a quarter of its citizens aged 65 years and over. Japanese productive age groups who are too busy working usually send their elderly parents to nursing homes, therefore Japan currently has many nursing homes to provide care to elderly, even with nurses "imported" from abroad, including Indonesia.

Increasing the number of elderly also occurs in Indonesia, especially in Bali. (Pratiwi $\&$ Lestari, 2019) mentions that the number of elderly people in Bali province is included in the category of four old structured societies, estimated at around 517,500 people, while 15,579 people are displaced from the 4.5 million population. The elderly in Bali who have been abandoned by their families, or even who do not have families at all are also accommodated in nursing homes.

Elderly who live in nursing homes have conditions that make them dependent on assistance from the institution, such as medicine, hygiene and social activities (Forsgren, Skott, Hartelius, \& Saldert, 2016). In the nursing home, caregiver-elderly communication is a fundamental component of clinical practice in order to build a therapeutic relationship between them. Elderly-centered communication is critical to good patient care 
which drives treatment planning through the transmission of information and provides a therapeutic and supportive environment for the elderly (Dewi, Purwaningsih, \& Lindawati, 2017). According to O'Byrne in (McMullan, Parush, \& Momtahan, 2015), communication with patients (in this study of the elderly) is one of the most important points in the process of care and information exchange.

Like the relationship between caregiver and elderly, communication skills, especially the care givers, are important for the personal needs of the elderly in nursing homes (Forsgren et al., 2016). Care givers are the closest people who communicate directly with the elderly. Communication which is done can be called interpersonal communication which is a process of direct exchange of information or transfer of understanding of two or more people. Good interpersonal communication will build closeness and intimacy in the process of delivering messages. One important process of interpersonal communication is in the morning at a nursing home, when staff assists residents by getting out of bed and managing morning routines in nursing homes (Forsgren et al., 2016).

The comfortable feeling of the elderly in nursing homes is influenced by communication by care givers in the process of activities carried out between care givers and the elderly. Good care givers-elderly patient communication allows patients to share significant information which is important to gain an accurate diagnosis of their problems, enable care givers to get a better understanding of the patient's demand and easily to reduce the symptom. Besides, good communication can increase patients' understanding and compliance for the treatment plans, improve patients' trust to the caregivers and also reduce stress.

There were some relevant previous studies which had been done about communication skill and nursing care practice. (Maskhuri, 2017) in his research entitled "Interpersonal Communication of Nursing with Elderly: Descriptive Study of Qualitative Communication of Nurses with Elderly at Nursing Home". This study found out the process of how to build closeness through the stages of social penetration. The nurses treat the elderly by growing a sense of comfort and creating an environment with a warm atmosphere filled with hospitality and comfort. That was the way that nurses did in building intimate closeness. (Karumi, 2016) in her research entitled "Role of Nurses in Communication Interprivate with further for Building Creativity (Case Study on the Tresna Werdha Nirwana Social Home Puri Samarinda)" had a goal to understand the role of nurses in interpersonal communication with patients in building creativity in the Tresna Werdha Nirwana Puri Samarinda Nursing Home. In additional, (Purwaningsih \& Dewi, 2019) in her research entitled "The Analysis of Speech Act in Verbal Communication between Healthcare Professional and Patients in Public Helath Centre Branch Kerobokan Kelod." This study had analysed the usage of speech act in providing health care to the patients.

Beside the three relevant previous study above, another related study also had been conducted by (Febrianita \& Hardjati, 2019) in their study entitled "The Power of Interpersonal Communication Skill in Enhancing Service Provision." This study explores the interpersonal communication skills of the educational staff and recognizes the power of this interpersonal communication. This research result finds that there are 3 interpersonal communication skills of educational staff area. Secondly, there are powers of the interpersonal communication skill which have made improvement to service providing in the work unit. The results of this research also explain whether maintaining interpersonal relationship enhances the service providing.

Based on this condition, the researchers were interested in analyzing the caregiver experiences in implementing interpersonal communication and also determining form of directive speech act used by caregivers in treating elderly in nursing home. The findings of this study were expected to enrich the linguistic review especially in communication. This study provides an overview of the use of communicative skill in handling patients. In addition, this study can also be used as a reference by subsequent researchers. The results of this study are expected to add insight or knowledge of the students or even the health care on ways to effectively communicate within provide health services to be easily understood by the patient in order to make service will be better.

\section{LITERATURE REVIEW}

Theoretical review is several concepts related with speech act, interpersonal communication, caregiver and elderly patients. 
Pragmatic Theory "Speech Act"

Pragmatic is the branch of linguistics which focuses on language and how it will be used by the speaker in conversation (Ariel, 2008). Pragmatically there are at least three kinds of actions that can be realized by the speaker, locution, illocution and perlocution speech act (Searle, 1985). Further explained that locution acts refer to the actual words uttered, illocution acts refer to an action performed by the speaker in producing a given utterance. The illocution act is closely connected with the speaker's intentions and can be divided into five namely representative, directive, commissive, expressive, and declarative. Perlocution act is the actual effect of the speaker's utterance to the addressee, therefore this act happens after the locution and illocution act are produced.

Searle also classifying the indices of the speech becomes (5) five groups: namely:

1. Representative, namely the speech that binds the speaker to the truth of the proposition disclosed, for example stating, suggesting, boasting, complaining, and claim.

2. Directive, speech intended for the speech partner to take action according to speech, for example, ordering, ordering, pleading, advising, and recommend.

3. Commissive, i.e. actions that require the speaker to commit to something in the future. Examples are promises, swearing, rejecting, threatening, and guaranteeing.

4. Expressive, namely the expression of attitudes and feelings about a situation or reaction to people's attitudes and actions. Examples of congratulations, give thanks, regret, apologize, welcome, and give thanks.

5. Declarative, i.e. illocution which causes changes or conformity between proposition and reality. Examples are baptizing, firing, giving names, and punish.

\section{Interpersonal Communication}

Interpersonal communication is a kind of communication in which people communicate their feeling, ideas, emotions and information face to face to each other (DeVito, 2013). It can be classified into:

1. Verbal communication: Information communicated through speaking.

2. Nonverbal communication: Information communicated without being spoken, including eye contact, gesture, body

\section{language.}

Interpersonal communication is not only about what is said and what is received but also about how it is said, how the body language used, and what was the facial expression.

\section{Care Giver}

Care giver is an individual in general care for and supports other individuals (patients) in their lives (Awad \& Voruganti, 2008). Caregiver has a task as emotional support, caring for patients (bathing, dressing, preparing food, preparing medicine), managing finances, making decisions about care and communicating with formal health services (Kung, 2003).

\section{Elderly Patient}

Patients are everyone who conducts consultations on their health problems to obtain the necessary health services, both directly and indirectly in the hospital (Law Number 44 of 2009 concerning Hospitals). Elderly generally suffer from more than one disease. In fact, elderly patients are different from most patients. Elderly patients have a special way of treating them because they are not young anymore and most elderly patients have complex diseases and / or several diseases at the same time.

\section{METHOD}

The method used in this study was descriptive qualitative method with phenomenological approach which aimed to explore caregiver experience in caring for the elderly. The objective was to describe phenomena from the data analysis out of which a research conclusion was drawn. The analysis process used Colaizzi model with stages as follow: 1) Describe the phenomenon researched. 2) Collecting description of phenomena through opinions or participant statement via in-depth interview and observation techniques and making transcripts. 3) Reread the transcript interview results and quoting meaningful statements from all participants. 4) Elaborate the meanings in the statements are significant. 5) Organizing collection of meanings that are formulated into in the theme group. 6) Reading all categories, compare and search similarity between categories. 7) Write a complete description. 8) Meet with participants to do validation of the analysis result description. 9) Combine the validation data to in the description of the results of the analysis. In this study, the sample was selected through a purposive sampling 
method. The sample in this study consisted of 6 informants by conducting in-depth interviews. The researcher gave some questions to caregivers in nursing homes to find out how they communicate with the elderly in the nursing home and make observations about the communication activities occur.

\section{RESULTS AND DISCUSSION}

Based on objectives and the study conducted, therefore it was obtained the results of the study related to the caregiver experiences in implementing interpersonal communication and also the form of directive speech act used by caregivers in treating elderly in nursing home that can be described in the following discussion.

\section{Caregivers' Experiences In Implementing Interpersonal Communication}

Informants involved in this study was 6 students of STIKES Bina Usada Bali could be divided into two groups, they were 3 students who were undergoing caregiver in Japan nursing home and 3 others who were undergoing caregivers in Bali nursing home. Most of the informants were women and had bachelor education level. The length of time participants as caregivers for the elderly is quite diverse ranging from 1-4 years.

In providing care to the elderly, the majority of participants expressed feelings of annoyance and sometimes cranky at the beginning of their day working in the nursing home. Therefore, at the beginning they always try to smile at the elderly to establish closeness with them (showing non verbal interpersonal communication).

"Ada sih perasaan kesel saat mereka rewel, tapi saya juga kadang merasa kasihan. Saya jadi ngebayangin bagaimana kalau saya tua nanti." (DAR who worked in Bali nursing Home)

"Pernah merasa jengkel saat mereka cerewet. Saya cuma tarik nafas dan tersenyum. Saya berusaha untuk tetap lembut dalam melayani mereka" (PY who worked in Japan nursing home)

There were also informants who judge change in the elderly as a funny and natural thing happen to elderly. The informants also needed extra energy to be more patient in handling the elderly (nonverbal interpersonal communication) Some of them also felt difficulties and not confident in communicating with patients but it turns out they respect them more (verbal communication).

"kadang ada nenek/kakek lapor ke senior bilang belum makan, padahal baru saja diberi makan. Ya lucu aja, namanya juga lansia." (NR who worked in Bali nursing Home)

"Pertama kali kerja di Jepang, saya merasa canggung untuk berkomunikasi dengan lansia. Takutnya tidak sopan meskipun saya telah mengikuti program belajar bahasa jepang namun ada rasa canggung. Saya kesulitan mendengar aksen mereka. Saya selalu bilang maaf dan membungkuk, namun mereka maklum" (EW who worked in Japan nursing home)

The growth of awareness and sincerity of informants in providing care for the elderly becomes the main meaning of experience expressed by all informants. They tried to enjoy the role of care members to the elderly.

"Saya harus menikmatinya, kadang memang sedih, kesel. tapi gimana lagi saya kan sudah mutusin mengambil profesi ini, jadi dinikmati aja".(EW who worked in Japan nursing home)

"Sempet sih saya menggerutu saking kesalnya. Tapi, saya ingat kakek nenek dan orang tua saya di rumah. Prinsip saya, sekarang saya merawat sepenuh hati, pas saya tua nanti saya yang akan dirawat dengan baik." (AS who worked in Bali nursing home)

"I think caring elderly is an important experience that I can apply when I am in Bali later." (WP who worked in Japan nursing home)

Most informants provide basic care to the elderly by focusing on meeting the physiological needs (eating and drinking) to maximize the physical health of the elderly, and also provide fulfillment needs for elimination. To do this work most of them applied verbal interpersonal communication.

"Kami di sini mengatur pemberian obat (kusuri oagemasu). Ketika memberi obat, kami mengarahkan mereka untuk membuka mulut. Kalau pasiennya agak tidak mendengar kami berbicara lebih dekat dengan pasien atau berbicara di dekat telinga pasien". (EW who worked in Japan nursing home)

"kami juga membantu lansia yang tidak bisa ke toilet sendiri dengan bantuan dua orang caregiver yaitu orang pertama menggendong dari depan dan orang kedua di belakang lansia. Kami juga membantu membuka popok yang basah/kotor" (PY who 
worked in Japan nursing home)

The informants also compared their experiences as caregiver in different country including how they communicate, the facilities, their feelings and also their responsibilities

"In Japan, during my internship for two years, the task of caring elderly is the duty of the doctors so I couldn't carry out clinical nursing action. I only help providing nutritional needs orally, giving oral medication as suggested by the nurses, supporting personal hygiene, and making them comfort from disorientation. But in Bali, I am too busy caring the patient, so I don't have opportunity to listen elderly expectation or complaint different with my experience in Japan." (WP who worked in Japan nursing home)

"Setiap rumah sakit memiliki SOP tersendiri. Pekerjaan caregiver di Jepang lebih cekatan, jam kerja lebih panjan, keluhan lansia harus didengarkan. Perawatnya sangat toleran dengan caregiver di sana dan fasilitasnya juga lengkap. Di sini kami sangat dihargai meskipun kami orang asing. Bedanya dengan di Bali, lansia di Jepang tidak akan merasakan penurunan kondisi kesehatannya karena faktor usia. Mereka masih bisa pergi berbelanja, memotong rambut atau bahkan makan di kafe.

Based on the data obtained it can be concluded that experience is an event that has been experienced by someone both from within himself and from his environment. In this study a variety of perceptions arose in caregivers in caring for the elderly. Feelings arose in a variety of conditions, sometimes happy, upset, accepting, or allowing and so on. But awareness of caring for the elderly is seen as an obligation for caregivers. This perspective became a system that needed to be maintained, because it was a mirror that every individual will experience aging process.

Besides, the main point of giving satisfaction to the elderly was trust. It was revealed in an interview with six caregivers. They stated that the aim of treatment was to heal so that they believed that that the purpose of treatment is to get well therefore the elderly trusted the medical staff, especially caregivers and nurses who treated them because they were considered to know more about their illnesses and the best way to treat it. The feeling of comfort in the elderly in nursing homes is affected by communication performed by nurses in the process of activities carried out between nurses and the elderly. During the nursing practice, some difficulties were found including: a barrier for nurses when delivering messages to the elderly is the physical and mental decline of the elderly which causes disruption to communicate. Nurses must have skills in that regard. The importance of interpersonal communication here is as a container or a way to build a closeness that will later established an intimate relationship.

\section{Form Of Directive Speech Act Used By Elderly Caregivers}

Caregivers need to have the ability to communicate effectively with patients in order to achieve the desirable therapeutic outcome. Caregivers, through communication skills, can recognize the patient's healthcare needs, as a meaningful communication with patients enable caregivers aspire to enhance a thorough knowledge of individual patients and their personal characteristics.

\section{Prohibition} uyah nah."

"Odah....jani bedikin nak ngajeng misi

The nurse used the Balinese language in this context because she talked to the elderly and to show politeness. The utterance showed illocutionary (speech) acts typed directive speech act which attempted by the speaker to get the addressee not to do something.

“Kak jak odah, jani liun ngajeng sayur nggih, bedikin ngajeng be utawi ulam"

This utterance used to prohibit the elderly not to consume more meat. But if it is expressed directly, the elderly may feel not satisfied with the service. The word "nggih" used to emphasize the politeness of the utterance.

\section{Imperative}

\section{"Okuchi akete kudasai"}

This utterance commanded the elderly to open their mouth while the caregiver administering medication for them.

"Obaasan, suwatte kudasai!"

The context of utterance used while in toile. The caregivers help the elderly to get up from the wheelchair and sit on the toilet seat.

\section{Question}

\section{"Obasan gohan o tabemasuka"}

This utterance used by elderly caregiver in Japan to gain information whether the already had alredy eaten or not.

"Toire ikitain desuka?" 
When the caregiver help the elderly for the elimination. The caregiver asked question whether they need some help to go to the toilet or even for water elimination and others.

\section{CONCLUSION}

Building on the objectives and the results obtained from the discussion above, thus it can be drawn the conclusion that interpersonal communication is very important and is needed to form a relationship which in this case the caregiver and the elderly. The condition of the elderly who need it more attention and support makes caregiver more sensitive and understanding every elderly character in terms of communication. Moreover, caregivers need to have the ability to communicate effectively with elderly. In this study the utterance used by caregivers in treating the elderly was directive speech act including prohibition, imperative, and question. Researchers suggest that intensity a meeting between nurses and the elderly is added, so that the closeness that has been established can be maintained. The intensity of the meeting more certainly can have an effect better for the elderly.

\section{REFERENCE}

Ariel, M. (2008). Pragmatics and Grammar. Cambridge: Cambridge University Press. Retrieved from https://doi.org/10.1017/ CBO9780511791314

Awad, A. G., \& Voruganti, L. N. P. (2008). The Burden of Schizophrenia on Caregivers. Journal of Pharmacoeconomics, 26(2), 149162. Retrieved from https:// link.springer.com/article/10.2165/00019053200826020-00005

DeVito, J. A. (2013). The Interpersonal Communication Book 13th Edition. United States of America: Pearson Education Limited.

Dewi, S. P. A. A. P., Purwaningsih, N. K., \& Lindawati, N. P. (2017). Diction Analysis in making Empathetic responses for Diabetic of Nursing Student in STIKES Bina Usada Bali. LITERAn Jurnal Litera Bahasa Dan Sastra, 3(1), 88-97. Retrieved from https:// jurnal.undhirabali.ac.id/index.php/litera/ article/view/716

Febrianita, R., \& Hardjati, S. (2019). The Power of Interpersonal Communication Skill in Enhancing Service Provision. Journal of Social Science Research, 14, 3192-3199. Retrieved from https://doi.org/10.24297/ jssr.v14i0.8150

Forsgren, E., Skott, C., Hartelius, L., \& Saldert, C.
(2016). Communicative barriers and resources in nursing homes from the enrolled nurses' perspective: A qualitative interview study. International Journal of Nursing Studies, 54, 112-121. Retrieved from https:// doi.org/10.1016/j.ijnurstu.2015.05.006

Karumi, A. N. (2016). Peran Perawat dalam Komunikasi Antarpribadi dengan Lansia untuk Membangun Kreativitas (Studi Kasus di Panti Sosial Tresna Werdha Nirwana Puri Samarinda). E-Journal Ilmu Komunikasi, 4 (2), 102 - 111. Retrieved from https:// ejournal.ilkom.fisip-unmul.ac.id/site/wpcontent/uploads/2016/05/Jurnal(05-13-16-07 $-21-58) \cdot p d f$

Kung, W. B. (2003). Chinese American Caregiver of Patient with Schizophrenia, Family Challenges. New York: Guildford.

Maskhuri, S. A. (2017). Komunikasi Interpersonal Perawat Dengan Lansia (Studi Deskriptif Kualitatif Komunikasi Perawat Dengan Lansia di Panti Jompo Aisyiyah Kota Surakarta dalam Membangun Kedekatan). Program Studi Ilmu Komunikasi Fakultas Komunikasi Dan Informatika Universitas Muhammadiyah Surakarta. Retrieved from http://eprints.ums.ac.id/57170/1/Skripsi FORMAT PERPUS.pdf

McMullan, A., Parush, A., \& Momtahan, K. (2015). Transferring Patient Care: Patterns of Synchronous Bidisciplinary Communication Between Physicians and Nurses During Handoffs in a Critical Care Unit. Journal of Perianesthesia Nursing, 30(2), 92-104. Retrieved from https://doi.org/10.1016/ j.jopan.2014.05.009

Pratiwi, D. A. D. P., \& Lestari, M. D. (2019). Gambaran dukungan sosial dan penyesuaian diri pada perempuan pegawai negeri sipil prapensiun di Provinsi Bali. Jurnal Psikologi Udayana, 6(2), 328-336. Retrieved from https://doi.org/10.24843/

JPU.2019.v06.i02.p12

Purwaningsih, N. K., \& Dewi, S. P. A. A. P. (2019). The Analysis of Speech Act in Verbal Communication between Healthcare Professional and Patients in Public Health Centre Branch Kerobokan Kelod. Journal of English Educational Study (JEES), 2(1), 1120. Retrieved from http:// jurnal.stkippersada.ac.id/jurnal/index.php/ JEES/article/view/381

Saadati, H., Shoaee, F., Pouryan, A., Alkasir, E., \& Lashani, L. (2014). Effectiveness of Gestalt Group Therapy on Loneliness of Women Caregivers of Alzheimer Patients at Home. Iranian Rehabilitation Journal, 12(22), 54 58. Retrieved from https:// pdfs.semanticscholar.org/1f39/21921e2a77b 
Caregivers Experience in Performing Interpersonal Communication and Directive Speech Acts With Elderly in Japan and Bali Nursing Home

8167a2932999b36f3b14d763b.pdf?

$\mathrm{ga}=2.101350081 .1171215894 .1587009686-$

1086103979.1579841271

Searle, J. R. (1985). Expression and Meaning: Studies in the Theory of Speech Acts. Cambridge: Cambridge University Press. Retrieved from https://www.cambridge.org/ id/academic/subjects/philosophy/logic/ expression-and-meaning-studies-theoryspeech-acts?format $=\mathrm{PB}$ 